\title{
Was het maar zo makkelijk
}

Citation for published version (APA):

Wesseling, G. (2011). Was het maar zo makkelijk. Maastricht University. https://doi.org/10.26481/spe.20110421gw

Document status and date:

Published: 21/04/2011

DOI:

10.26481/spe.20110421gw

Document Version:

Publisher's PDF, also known as Version of record

\section{Please check the document version of this publication:}

- A submitted manuscript is the version of the article upon submission and before peer-review. There can be important differences between the submitted version and the official published version of record.

People interested in the research are advised to contact the author for the final version of the publication, or visit the DOI to the publisher's website.

- The final author version and the galley proof are versions of the publication after peer review.

- The final published version features the final layout of the paper including the volume, issue and page numbers.

Link to publication

\footnotetext{
General rights rights.

- You may freely distribute the URL identifying the publication in the public portal. please follow below link for the End User Agreement:

www.umlib.nl/taverne-license

Take down policy

If you believe that this document breaches copyright please contact us at:

repository@maastrichtuniversity.nl

providing details and we will investigate your claim.
}

Copyright and moral rights for the publications made accessible in the public portal are retained by the authors and/or other copyright owners and it is a condition of accessing publications that users recognise and abide by the legal requirements associated with these

- Users may download and print one copy of any publication from the public portal for the purpose of private study or research.

- You may not further distribute the material or use it for any profit-making activity or commercial gain

If the publication is distributed under the terms of Article $25 \mathrm{fa}$ of the Dutch Copyright Act, indicated by the "Taverne" license above, 


\section{Maastricht University}

Prof. dr. G. Wesseling

Faculty of Health, Medicine and Life Sciences

Was het maar zo makkelijk

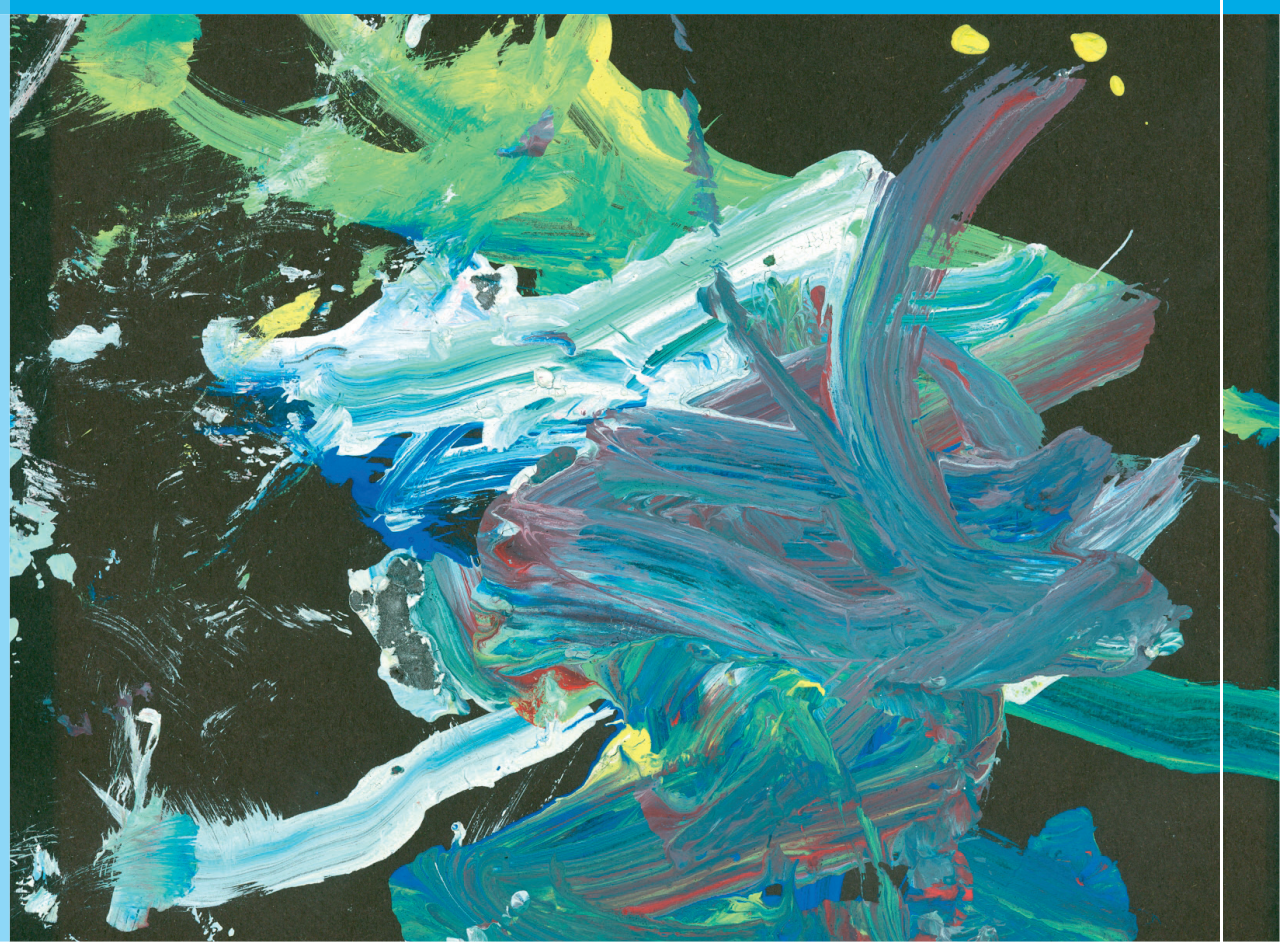


Was het maar zo makkelijk 


\section{Colofon}

Ontwerp en print: Océ Business Services, Maastricht

ISBN: 978-905-681-362-8

NUR: 870

Alle rechten voorbehouden. Niets uit deze uitgave mag worden verveelvoudigd, opgeslagen in een geautomatiseerd gegevensbestand of openbaar gemaakt worden, zonder voorafgaande schriftelijke toestemming van de auteur of uitgever. 


\title{
Was het maar zo makkelijk
}

\author{
Rede \\ uitgesproken bij de aanvaarding van het ambt van bijzonder \\ hoogleraar longziekten in het bijzonder management van chronische \\ obstructieve longaandoeningen aan de Faculty of Health, Medicine and \\ Life Sciences van de Universiteit Maastricht.
}

Maastricht, 21 april 2011

prof. dr. G. Wesseling 
Was het maar zo makkelijk 


\section{Inhoudsopgave}

Inleiding

Epidemiologie van chronische obstructieve longaandoeningen $\quad 7$

$\begin{array}{ll}\text { Prevalentie } & 9\end{array}$

$\begin{array}{ll}\text { Vroegdiagnostiek } & 12\end{array}$

Management van obstructieve longaandoeningen $\quad 12$

$\begin{array}{ll}\text { Farmacotherapie } & 17\end{array}$

$\begin{array}{ll}\text { Zorglogistiek } & 18\end{array}$

$\begin{array}{ll}\text { Cystic fibrosis } & 21\end{array}$

Dossiervorming 24

$\begin{array}{ll}\text { Onderwijs } & 25\end{array}$

Samenvatting, conclusies en woorden van dank 26 
Was het maar zo makkelijk 


\section{Inleiding}

Mijnheer de rector magnificus, waarde collega's, lieve familieleden en vrienden, geachte toehoorders.

Probeert $u$ het zich eens voor te stellen. 2 Mannen staan ergens in een café in Maastricht aan de bar, de ene met een glaasje fris, de andere met een biertje. Het gesprek gaat over het bezoek aan de huisarts van de eerste. Het gaat in het Maastrichts maar ik zal het $u$ en mezelf niet aandoen om te proberen dat hier na te doen.

"Ik heb COLA zegt nummer één. Dat zie ik zegt de ander, maar wat moest je nou bij de huisarts?"

Zo verging het jarenlang patiënten met COPD. Een afkorting waar veel mensen zich niets bij konden en zelfs ook nu nog kunnen voorstellen.

In deze oratie zal ik eerst ingaan op wat we precies verstaan onder chronische obstructieve longaandoeningen, COLA zogezegd, en wat anno 2011 de betekenis ervan is voor de samenleving en voor de individuele patiënten voor ons als behandelaars. Vervolgens zal ik stilstaan bij een aantal voor deze leerstoel relevante aspecten van de zorg voor en het management van chronische obstructieve longaandoeningen en bij de plaats die ze innemen in het onderzoek en het onderwijs in Nederland in het algemeen en in onze regio en in onze faculteit in het bijzonder. Ik hoop te eindigen met een schets van mijn eigen rol daarin, nu en in de toekomst.

\section{Epidemiologie van chronische obstructieve longaandoeningen}

Reeds in het midden van de $19^{\mathrm{e}}$ eeuw werd door John Hutchinson aangetoond dat een verminderde longinhoud geassocieerd is met een verminderde levensverwachting?.

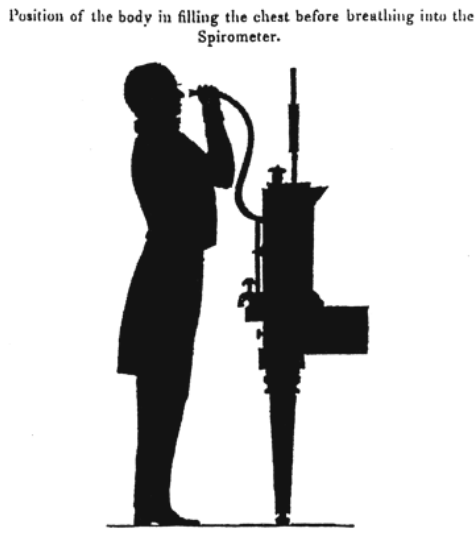


Niet voor niets noemde hij de totale hoeveelheid lucht die iemand maximaal kan uitademen de vitale capaciteit. Aanvankelijk waren het overigens vooral de cardiologen die de longfunctie van patiënten meenamen in de risico-inschatting van hun patiënten.

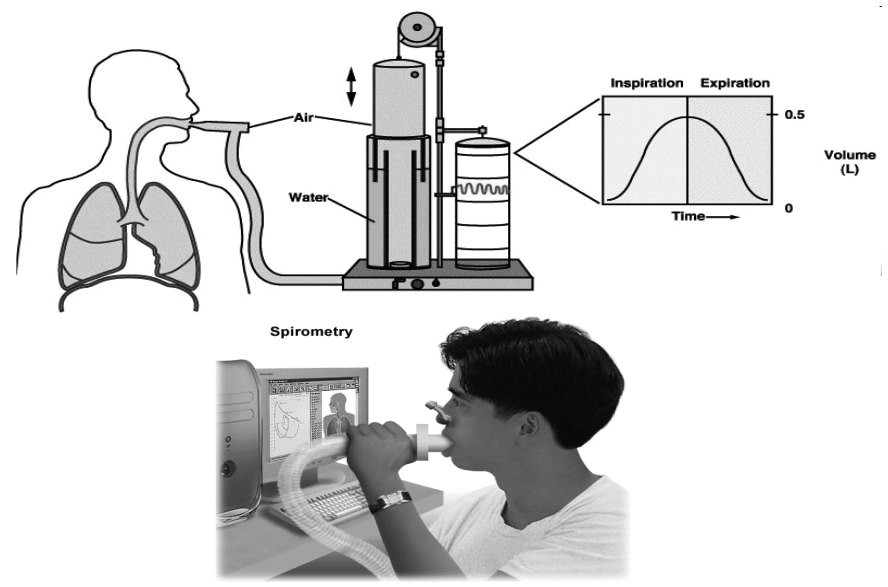

Pas in de tweede helft van de zoe eeuw werd luchtwegvernauwing of bronchusobstructie zoals we die met spirometrie kunnen detecteren bij een aantal chronische longaandoeningen nader bestudeerd aan de hand van de één-seconde waarde en de zogenaamde Tiffeneau-index als maat voor luchtwegvernauwing ${ }^{2}$.

Chronisch obstructieve longaandoeningen hebben daarna in de afgelopen decennia een enorme ontwikkeling doorgemaakt.

Dat begon met CARA, de afkorting van chronisch aspecifieke respiratoire aandoeningen. Respiratoir wil zeggen betrekking hebbend op de ademhaling. In de optiek van de veelgeroemde maar steeds omstreden Dutch Hypothesis werden onder CARA verschillende aandoeningen samengevat waarbij allergisch astma met volledige reversibiliteit van de luchtwegvernauwing de ene kant van het spectrum vormde en volledig onomkeerbare luchtwegvernauwing met emfyseem ten gevolge van jarenlang roken van sigaretten de andere kant ${ }^{3}$. Die aandoeningen zouden een zodanig gelijkaardige basis hebben dat het gepast werd geacht om ze onder één noemer samen te vatten. Elders in de wereld is lang getwijfeld aan dit concept. Later is ook in Nederland de afkorting CARA in onbruik geraakt. Dat kwam enerzijds omdat met name het woord aspecifiek niet gepast bleek, en anderzijds omdat de Dutch 
Hypothesis in onbruik raakte. Toen ik halverwege de jaren ' 80 met mijn opleiding tot longarts begon had je astma, COPD en een mengvorm die we heel lang chronische astmatisch bronchitis hebben genoemd. Ik moet u zeggen dat ik aan die term nog met een zekere weemoed terug denk. Het betroffen astmapatiënten die zoveel hadden gerookt of dermate lang onderbehandeld waren geweest dat de luchtwegvernauwing gedeeltelijk onomkeerbaar en permanent was geworden. Astma is sindsdien wel zo ongeveer astma gebleven en voor chronische astmatische bronchitis is vooral in de eerste lijn en vastgelegd in de vorige standaard van het Nederlands Huisartsen Genootschap de omschrijving astma met persisterende bronchusobstructie in de plaats gekomen. Ook aan die term denk ik met weemoed terug. En COPD is inmiddels een verzamelbegrip geworden voor een breed palet van respiratoire en systemische stoornissen 4 .

\section{Prevalentie}

Wat de afgelopen 25 jaar overziend ook opvalt is de toename in het aantal patiënten met COLA. In 2010 kreeg 8\% van de Nederlandse bevolking tenminste 1 medicament voorgeschreven ter behandeling van een obstructieve longaandoening 5 .

Naar schatting lijden er in Nederland ongeveer 550.000 mensen aan astma, en dat aantal neemt eerder toe dan af ${ }^{6}$. De diagnose astma wordt vanaf de vroege kinderleeftijd gesteld en het aantal patiënten blijft met het vorderen van de leeftijd betrekkelijk stabiel.

Astma heeft een zekere genetische basis. Het idee is dat omgevingsfactoren bij een persoon met een genetische aanleg voor het krijgen van astma resulteren in het tot ontwikkeling, met een ander woord, tot expressie komen van de ziekte. Aan de genetische aanleg valt niet veel te doen maar lang is gedacht dat omgevingsfactoren die bijdragen aan de kans op het krijgen van astma beïnvloed kunnen worden. Het geven van borstvoeding en het vermijden van blootstelling aan sigarettenrook en allergenen leken nuttige maatregelen om de kans op het krijgen van astma te verkleinen. Daarnaar is ook binnen onze UMC maar ook elders in Nederland jarenlang onderzoek gedaan. Dat is zeer bewerkelijk onderzoek gebleken. De voor het onderzoek vaak zeer gemotiveerde ouders hebben zich grote inspanningen getroost om alle adviezen op te volgen en de jonge kinderen die de onderzoekspopulatie vormden moesten jarenlang worden opgevolgd. Daarbij is aangetoond dat geïsoleerde maatregelen om blootstelling te verminderen en daarmee de kans op het krijgen van astma te verkleinen niet effectief zijn. 
Ook een zeer vroegtijdige behandeling met ontstekingsremmers leverde niet het gewenste resultaat op, zo bleek uit onze zogenaamde At-Risk studie. Alleen samengestelde interventies gericht op het verminderen van het contact met voedingsallergenen en inhalatieallergenen verminderen de kans op het ontwikkelen van astma in hoogrisicokinderen?. Dergelijke maatregelen zijn in de praktijk evenwel nauwelijks te implementeren en vol te houden. Astma zal derhalve de komende decennia de wereld nog niet uit zijn. Voorkomen zal niet mogelijk zijn, behandelen gelukkig wel. Er bestaan verschillende effectieve ontstekingsremmers en luchtwegverwijders waarmee een aanzienlijk deel van de astmapatiënten een min of meer normaal leven zou moeten kunnen leiden. Dat leren ons immers de grote placebogecontroleerde studies die de basis vormen voor de richtlijnen voor de behandeling van astma. De werkelijkheid is echter dat de ziektelast van patiënten met astma ook in onze Westerse wereld hoog blijft. Onderzoek in verschillende Europese landen toont aan dat ook in geval van het voorschrijven van geneesmiddelen veel astmapatiënten allerhande hinderlijke klachten van hun astma blijven houden ${ }^{8}$. Een mogelijke verklaring voor het persisteren van de klachten is het feit dat patiënten hun medicamenten niet of niet op de juiste wijze gebruiken. Inderdaad is de geschatte therapietrouw bij patiënten met een chronische aandoening lang niet altijd optimaal. Cijfers voor astma variëren van 35 tot $60 \%$. Met andere woorden: ongeveer de helft van de patiënten gebruikt de medicatie niet volgens voorschrift. Dat komt wellicht omdat wij het belang van het gebruik ervan onvoldoende benadrukken of omdat onze instructies niet goed genoeg zijn. Daar wordt met de komst van de gespecialiseerde verpleegkundigen en praktijkondersteuners al veel aan gedaan, maar zelfs dan blijven patiënten hun medicamenten slordig gebruiken. Als het weer wat beter gaat dan wordt de therapietrouw snel minder, zo leert onze ervaring. Dat geldt overigens niet alleen voor inhalatiemedicatie voor patiënten met obstructieve luchtwegaandoeningen maar ook voor een aantal andere chronische ziekten. Het feit dat veel patiënten slordig zijn met hun medicatie doet overigens vermoeden dat patiënten bereid zijn om een zekere ziektelast te ervaren. Er is jammer genoeg maar weinig onderzoek gedaan naar factoren die van invloed zijn op de bereidheid of het vermogen van patiënten om medicatieadviezen en -voorschriften op te blijven volgen. Kwaliteit van de instructies en de educatie, socio-economische achtergrond van de patiënt, angst voor bijwerkingen, eerdere ervaringen met een bepaald medicament en een verkeerde keuze in de voor een bepaald medicament beschikbare toedieningsvormen kunnen daarbij een rol spelen. 


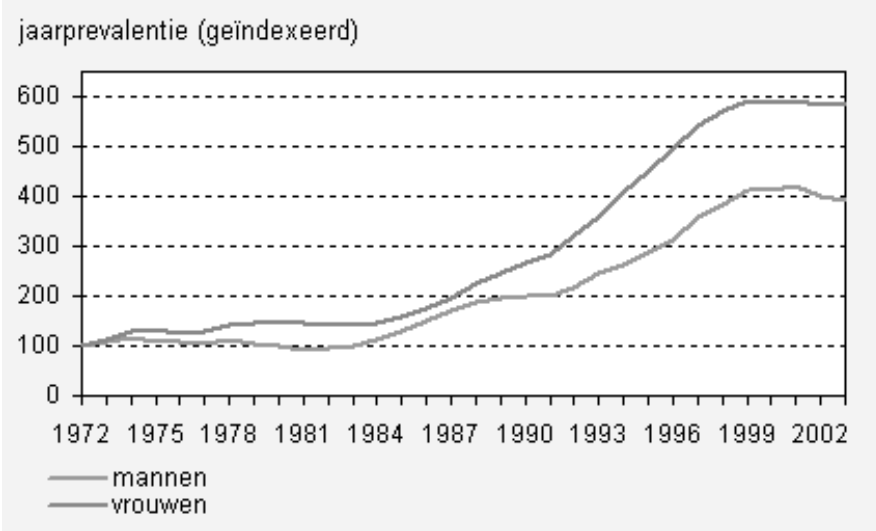

Op 1 januari 2007 waren er volgens een opgave van het RIVM 330.000 mensen met COPD ${ }^{9}$. De afgelopen jaren nam het aantal patiënten met ongeveer 33.000 per jaar toe. Die toename is deels te verklaren met een feitelijke toename van het aantal patiënten en deels doordat de inspanningen om patiënten met COPD in beeld te krijgen de afgelopen jaren zijn toegenomen. Zoals $u$ ziet wordt de diagnose COPD zelden onder de leeftijd van 40 jaar gesteld en neemt het aantal patiënten sterk toe met vorderende leeftijd. Bovendien lopen er naar schatting 150.000 tot 250.000 mensen rond met COPD die zich nog niet met longklachten bij de huisarts hebben gemeld of bij wie de diagnose nog niet werd gesteld.

\section{prevalentie (per 1.000)}

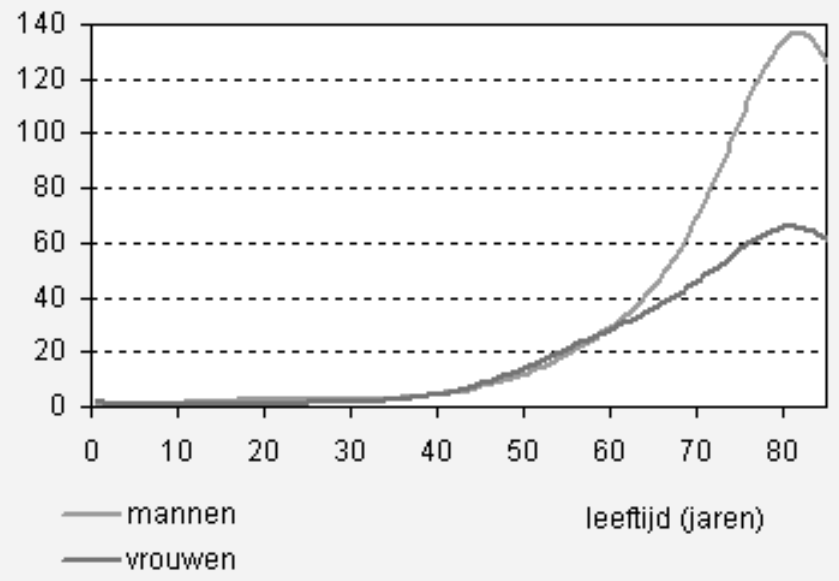




\section{Vroegdiagnostiek}

Over deze onderdiagnostiek van COPD is de laatste jaren veel te doen geweest. Zelfs als we ervan uitgaan dat de aantallen kloppen is de vraag of dat erg is. Lang niet iedere patiënt bij wie een zekere mate van luchtwegobstructie wordt gevonden en bij wie de diagnose COPD wordt gesteld heeft tengevolge van zijn of haar COPD beperkingen die behandeling behoeven. Bij veel patiënten, al dan niet met luchtwegklachten, bij wie door gerichte screeningsprogramma's een diagnose COPD wordt gesteld is sprake van licht of hooguit matig COPD en bestaat geen noodzaak voor medicamenteuze behandeling ${ }^{10}$. Voor hen gelden geen andere adviezen dan de adviezen die we ook geven aan mensen zonder COPD: niet roken, voldoende bewegen en zorgen voor een goede voeding en voedingstoestand. Andere interventies waarmee het beloop van de ziekte daadwerkelijk kan worden beïnvloed zijn er immers niet. Zorgvuldige bestudering van nieuw verzamelde resultaten van laagdrempelige diagnostiek gecombineerd met geprotocolleerde opvolging zoals die nu in de regio Maastricht/Heuvelland is ingericht, mogelijk aangevuld met gegevens uit de zeer omvangrijke binnenkort op te starten Maastricht-studie kunnen nieuw licht werpen op het nut en de doelmatigheid van vroegdiagnostiek en vroegtijdig ingrijpen in gevallen van min of meer bij toeval gediagnosticeerd COPD.

\section{Management van obstructieve longaandoeningen}

In alle gevallen van COLA geldt: (erger) voorkomen is beter dan niet genezen.

Vast staat dat stoppen met roken belangrijk is voor patiënten met longaandoeningen, meer nog zelfs dan voor patiënten met vooralsnog gezonde longen.

Roken versterkt het ontstekingsproces dat aan de basis ligt van astma en is veruit de belangrijkste oorzaak van COPD. Stoppen met roken dus. Als dat nou eens gemakkelijk was. Marc Willemsen die hier enkele maanden gelden stond voor het uitspreken van zijn oratie als hoogleraar tabaksontmoediging aan deze universiteit merkte daarover al op dat we het voorlopig nog niet gewonnen hebben van de tabaksfabrikanten als het gaat om roken in Nederland. Daarom blijft begeleiding bij en advies over stoppen met roken ook in de spreekkamer een belangrijk onderdeel van de zorg.

Daarbij past overigens een zekere bescheidenheid. Het European Network for Smoking Prevention deed onderzoek naar de effectiviteit van de verschillende manieren om het roken van sigaretten terug te dringen ${ }^{11}$. 
Opvallend genoeg blijken overheidsmaatregelen en publiekscampagnes meer op te leveren dan individuele interventies in de spreekkamer van de behandelaar. Vooral bij jongeren en rokers met een laag inkomen zijn accijnsverhogingen het meest effectief, gevold door een openbaar rookverbod. Herhaalde mediacampagnes en een reclameverbod werken eveneens maar de opbrengst van gezondheidswaarschuwingen en van een individueel rookstopadvies in de spreekkamer is teleurstellend. Onze UMC heeft een voortreffelijke vakgroep gezondheidsvoorlichting, maar helaas druppelt de deskundigheid die daar wordt verzameld maar heel langzaam door in de spreekkamer. Veel behandelaars achten zich niet verantwoordelijk voor het rookgedrag van vooralsnog gezonde rokers. Dat is jammer, want zelfs als maar een enkeling stopt na het advies van de eigen huisarts, dan nog is het een zeer goedkope en ongetwijfeld zeer kosteneffectieve interventie. Naar schatting $4 \%$ van de rokers heeft aan het eenmalig advies van de huisarts voldoende om het roken definitief te laten ${ }^{12}$.

Wat opvalt uit een groot aantal studies is dat veel rokers, zonder gebruik te maken van bewezen effectieve hulpmiddelen, proberen om te stoppen. Ongeveer $80 \%$ van de mensen die ooit stopten met roken deden dat zonder gebruik te maken van medische interventies of hulpmiddelen. Die bewezen effectieve hulpmiddelen zijn er wel. Zowel van intensieve begeleiding en counseling, van nicotinevervangers als kauwgom en pleisters, van antidepressiva als de ouderwetse tricyclische antidepressiva als het meer recent geïntroduceerde bupropion en ook van varenicline is aangetoond dat de kans op succes van een poging om met roken te stoppen erdoor wordt vergroot. In de verschillende gepubliceerde studies stopt naar schatting 30 tot $35 \%$ van de rokers met een combinatie van intensieve begeleiding of counseling gecombineerd met nicotinevervangers en een antidepressivum of varenicline ${ }^{13}$. Daarnaast zijn er nog verschillende andere kunst- en hulpmiddelen waarmee driftig wordt geadverteerd maar waarmee nooit fatsoenlijk onderzoek werd gedaan en waarvan de werkzaamheid anders dan met $n=1$ waarnemingen niet kan worden beoordeeld. Denk daarbij aan acupunctuur, elektrische sigaretten, hypnose en hypnotherapie, laser, online videolessen en wat er nog meer aan behandelingen wordt aangeboden en gepromoot.

Farmacotherapie voor de behandeling van rookverslaving werd lange tijd niet vergoed, wat het gebruik ervan zeker niet bevorderd heeft. Gelukkig is kortgeleden besloten om ze onder voorwaarden wel te vergoeden, hoewel de praktische uitvoerbaarheid van de manier waarop 
de zorgverzekeraars daarvoor nu groen licht hebben gegeven zeer te wensen overlaat. Hopelijk zal nauwgezet worden geëvalueerd wat dat betekend heeft voor het feitelijk gebruik ervan en vooral van wat het heeft opgeleverd in de zin van succesvolle stoppen-met-roken pogingen. Echter, ook met begeleiding en hulpmiddelen is roken een hardnekkige verslaving en er zijn aanwijzingen dat rokers met longlijden nog meer moeite hebben om te stoppen dan zogenaamde gezonde rokers. Uitkomsten van een Engelse studie doen vermoeden dat je rokers met COPD kunt motiveren om te stoppen als je ze hun longleeftijd voorhoudt ${ }^{14}$. Daarmee wordt kort samengevat bedoeld: $u$ bent 60 maar $u$ heeft de longen van iemand van 75. Op de korte termijn stoppen met die aanpak wat meer mensen met roken, maar voor heel veel patiënten is dat toch onvoldoende motivatie. Dat past ook bij de bevindingen van de studie die Daniel Kotz in CAPHRI-verband deed naar het effect van confronteren van rokers met longfunctiebevindingen gecombineerd met intensieve begeleiding en gebruik van geneesmiddelen in een poging hen te laten stoppen met roken ${ }^{15}$. Hij vond ook een toename van de motivatie en van het aantal stoppers op de korte termijn. Er was echter na een jaar geen verschil met rokers die de uitslagen van het longfunctieonderzoek niet te horen hadden gekregen. Dat werpt ook een ander licht op initiatieven voor vroegdiagnostiek van COPD bij rokers. Als het voor de kans van slagen van een stoppen-met-roken poging toch niet uitmaakt of er sprake is van een gestoorde longfunctie en als andere interventies of farmacotherapie bij klachtenvrije COPDpatiënten niet zinvol zijn is vroegdiagnostiek dat wellicht ook niet.

Kortgeleden is CAPHRI, in casu Professor Onno van Schayck begonnen met de langverwachte nicotine-vaccinatiestudie. Het idee achter deze vaccinatie is dat door de vorming van grote moleculen door binding van nicotine aan specifieke antilichamen de passage van nicotine door de bloed-hersenbarriëre kan worden voorkomen. Het resultaat daarvan zal naar wordt verondersteld zijn dat de roker niet meer de onmiddellijke dopaminerge kick krijgt waar het om te doen is en vervolgens het roken zal laten omdat er niet veel meer aan is.

Totdat de uitkomsten van die studie en van andere wetenschappelijke studies naar gedragsmatige of medicamenteuze interventies om rokers te laten stoppen beschikbaar zijn, moeten we het doen met wat we hebben, en dat gebeurt zoals al gezegd in de praktijk maar mondjesmaat. Ik heb altijd de hoop gehad dat de komst van de praktijkondersteuners in de eerste lijn een boost zou geven aan het bevorderen van een 
gezonde leefstijl onder patiënten maar bij voorkeur ook bij mensen die nog geen patiënt zijn. Inderdaad zijn POH's vrijwel altijd betrokken bij de eerstelijns zorg voor verschillende chronische ziekten. De meesten hebben technieken voor motivational interviewing bij het geven van leefstijladviezen in de bagage en in het takenpakket. Begeleiding door $\mathrm{POH}^{\prime}$ s bij het aanleren en onderhouden van een gezonde leefstijl wordt onder de huidige omstandigheden vergoed bij patiënten met een chronische ziekte maar nu nog niet bij vooralsnog gezonde bij de huisarts ingeschreven patiënten, en dan ook nog als onderdeel van een $\mathrm{dbc}$ gekoppeld aan één specifieke ziekte en niet als generieke module wanneer nog geen sprake is van ziekte.

Bovendien is de agenda van de meeste POH's de afgelopen paar jaar snel dichtgeslibd en zijn begeleiding en counseling tijdrovend. Naast stoppen met roken is ook bewegen daarbij van groot belang. Te weinig lichaamsbeweging is een belangrijke factor bij de zich ontwikkelende beperkingen waarmee COPD gepaard gaat. Die beperkingen worden namelijk niet alleen bepaald door de ernst van de longfunctiestoornissen maar zeker ook door de algehele lichamelijke conditie van de patiënt. Ook het hart en vooral ook de skeletspieren zijn daarbij van belang. Bekend is dat rokers minder bewegen dan niet-rokers en dat patiënten met COPD minder bewegen dan mensen die geen COPD hebben.

\section{Clinical course of COPD}

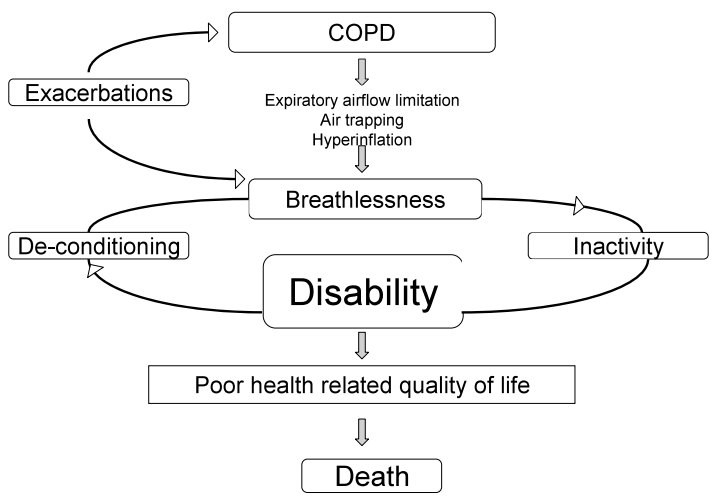

In de figuur wordt weergegeven hoe longfunctiestoornissen en inactiviteit elkaar beïnvloeden als het gaat om de toenemende beperkingen die COPD patiënten ervaren. Lichamelijke inactiviteit leidt 
tot een afname van de spiermassa. Eén van de eerste en mogelijk ook belangrijkste spiergroepen die daarmee te maken krijgen zijn de bovenbeens- of quadricepsspieren. Die hebben we nodig om op te staan uit onze stoel, om te lopen en om de trap op te gaan. Die moet je dus in vorm houden en trainen. Dat zou een patiënt ook zelf moeten kunnen maar steeds vaker gebeurt dat via fysiotherapie, reactivatie en revalidatie of via zogenaamde beweegprogramma's in de eerste lijn. Ook in het geval van meer bewegen geldt, net zoals we zojuist ook al zagen in het geval van roken, dat de patiënt niet gemakkelijk ander gedrag aanleert en vol houdt. De beweegprogramma's, zoals die nu onder meer in MUMC+ verband door Professor Rob de Bie en zijn team worden ontwikkeld en uitgetest zijn niet alleen bedoeld om de patiënt in beweging te krijgen maar vooral om die in beweging te houden en om te voorkomen dat gezondheidsbevorderend gedrag tot in lengte van jaren afhankelijk is van zorgverleners en dus geld blijft kosten.

Het liefste zou je al die leefstijladviezen integreren in de reguliere zorg. Samen met Jean Muris van huisartsgeneeskunde en onze longverpleegkundigen begonnen we een aantal jaren geleden al met een onderzoekssubsidie van PICASSO voor COPD de zogenaamde NIMCO studie, naar de effecten van verschillende, geïntegreerde nietmedicamenteuze interventies bij patiënten met nieuw gediagnosticeerd licht tot matig ernstig COPD. Door hen uit te leggen wat het verloop van de ziekte COPD is en wat bij een onveranderde leefstijl het perspectief bij COPD kan zijn, probeerden we hen te motiveren te stoppen met roken, meer te bewegen en te zorgen voor een goede voedingstoestand. Het idee daarbij was dat educatie en begeleiding gericht op gezond leven het gedrag en de leefstijl van patiënten blijvend kan veranderen en dat motivatie om één aspect van gezond leven te beïnvloeden ook van invloed kan zijn op andere uitingen van een ongezonde leefstijl. De inclusie is helaas jammerlijk mislukt en dat lag zeker niet aan het enthousiasme van de longverpleegkundigen. Kort gezegd kwam het er op neer dat patiënten bij het schetsen van het perspectief zeiden: dat zien we dan wel weer. We waren er misschien wel te vroeg mee, want sindsdien zijn de bekendheid en het bewustzijn van het maatschappelijk belang van COPD duidelijk toegenomen, maar nog steeds geldt: voorkomen is beter dan niet genezen! Hopelijk kan de praktijkondersteuner in de huisartspraktijk straks wel wat ons destijds niet lukte. De tijd zal het leren en het is een zeer zorgvuldige bestudering waard.

Een gezonde leefstijl heeft alles te maken met gedrag en zelfmanagement. Ik kijk af en toe jaloers naar de vooruitgang die op dat terrein al gemaakt 
is als het gaat om diabetes mellitus. Voor patiënten met diabetes bestaat het DIEP, het diabetes interactief educatie programma ${ }^{16}$. DIEP is ontwikkeld vanuit het Academisch Ziekenhuis en de Universiteit van Maastricht, met steun van diverse organisaties. Het programma biedt betrouwbare informatie over de ziekte en de behandeling, en helpt $u$ bij het maken van keuzes in uw dagelijks leven. Veel van wat daarbij aangeboden wordt aan diabetes patiënten kan op vergelijkbare wijze worden aangeboden aan patiënten met astma en COPD. En dan noemen we het natuurlijk heel toepasselijk PIEP, Pulmonaal Interactief Educatie Programma. Daarmee is kortgeleden gelukkig een begin gemaakt in het kader van PICASSO voor COPD. PICASSO staat voor Partners in Care Solutions en is een disease management programma dat zich richt op de optimalisatie van de COPD-zorg in Nederland. Het is een samenwerkingsverband van de industrie en vertegenwoordigers van alle bij de zorg voor COPD betrokken partijen, met een voorname rol voor CAPHRI. Dit samenwerkingsverband ondersteunt onder andere wetenschappelijk onderzoek en regionale ketenzorgprojecten die een bijdrage leveren aan het verbeteren van die zorg. PIEP zou daar heel goed in passen en hopelijk kunnen we er met de bestaande kennis van DIEP een vliegende start mee maken.

\section{Farmacotherapie}

Zeker in de tweede lijn speelt de farmacotherapie van chronisch obstructieve longaandoeningen een grote rol. Inderdaad zullen er weinig astma of COPD patiënten de spreekkamer van de longarts verlaten zonder recept. Farmacotherapie heeft een voorname plaats in de richtlijnen, die gedetailleerde adviezen geven voor de medicamenteuze behandeling van astma en COPD. In een groot aantal placebogecontroleerde studies is het effect van de verschillende beschikbare medicamenten uitvoerig getest en aangetoond. Diezelfde studies laten evenwel zien dat lang niet alle patiënten, niet alleen in het geval van COPD maar ook in het geval van astma geheel en al klachtenvrij worden en dat er dus blijkbaar een deel van de ziektelast is dat zich aan het effect van de behandeling onttrekt. Bovendien dienen we ons te realiseren dat de uitkomsten van de grote placebo-gecontroleerde studies die aan de basis liggen van onze richtlijnen en protocollen het uiteindelijke effect van die medicamenten bij de patiënt die voor ons zit maar zeer ten dele voorspelt. Een mogelijke verklaring daarvoor is het feit dat de therapietrouw in studies vaak beter is dan in de dagelijkse praktijk. Bovendien worden veel patiënten uitgesloten voor deelname aan studies, bijvoorbeeld omwille van andere 
gelijktijdig aanwezige aandoeningen. Er werd recentelijk gesteld dat slechts 8 tot $10 \%$ van de COPD-patiënten in aanmerking zou komen voor een studie naar de effecten van geneesmiddelen ${ }^{17}$. Ook zijn studies vaak uitgevoerd bij zeer specifieke patiëntenpopulaties en worden de uitkomsten vervolgens geëxtrapoleerd naar andere categorieën patiënten. Tenslotte is inmiddels wel duidelijk dat een deel van de ziektelast van patiënten met COLA zich onttrekt aan de effecten van farmacotherapie. Dat geldt vanzelfsprekend voor COPD maar naar we nu weten ook voor astma.

Een bijkomende factor die wellicht in de zeer nabije toekomst van invloed kan zijn op het vertalen van onderzoeksbevindingen naar de dagelijkse praktijk is het feit dat wat experts in richtlijnen adviseren of waar patiënten menen baat bij te hebben niet noodzakelijkerwijs hetzelfde is als wat zorgverzekeraars bereid zijn om in te kopen of te vergoeden. Een voorbeeld betreft $\mathrm{N}$-acetylcysteïne, een middel dat jarenlang aan patiënten met COPD werd voorgeschreven, maar dat na twee recente negatieve studies niet meer voor vergoeding in aanmerking komt. Veel patiënten zweren er echter nog steeds bij en die halen het middel nu in België of bij de Aldi. Ook wordt het door experts soms geadviseerd voor patiënten met interstitiële aandoeningen, maar ook dan komt niet voor vergoeding in aanmerking. Een tweede voorbeeld betreft roflumilast, een nieuw middel dat een zekere anti-inflammatoire werking heeft bij COPD, door de Europese registratieautoriteiten is toegelaten, in een aantal Europese landen wordt vergoed, maar niet in Nederland. Dat is jammer want ieder nieuw medicament dat het beloop van COPD kan beïnvloeden is zeer welkom. Zoveel hebben we wat dat betreft immers niet in handen.

\section{Zorglogistiek}

In onze regio zijn met het ontwikkelen en implementeren van zorgprogramma's voor patiënten met chronische ziekten al flinke stappen gezet. De afdeling longziekten van het azM heeft al ongeveer 20 jaar geleden als één van de eersten het longfunctielaboratorium opengesteld voor aanvragen voor spirometrie van de huisarts. Later introduceerden we een shared care model voor patiënten met COPD die indien stabiel werden terugverwezen naar de huisarts om in de huisartspraktijk te worden opgevolgd door een gespecialiseerde verpleegkundige ${ }^{18}$. Nog weer later kwam een disease managementprogramma voor patiënten met astma en COPD. Dit programma voorzag erin dat de diagnostiek en begeleiding van patiënten met licht tot matig astma of COPD plaatsvond 
in de huisartspraktijk door gespecialiseerde verpleegkundigen, onder verantwoordelijkheid van de huisarts en onder supervisie van de longarts ${ }^{19}$.

Sinds 2008 hebben we in de regio één van de eerste keten-DBC's voor COPD. Daarbij is de zorggroep, in ons geval de RHZ de hoofdaannemer voor het totaal van de eerstelijns zorg en zijn andere zorgverleners onderaannemers. Denk daarbij aan fysiotherapeuten voor het verzorgen van beweegprogramma's, maar tot op zekere hoogte ook aan longartsen. Onderdeel van de in dit verband gemaakte afspraken is dat de longarts beschikbaar is voor patiënten die niet formeel naar de tweede lijn verwezen zijn. Het is lang zo geweest dat verwijzing de enige manier was om de expertise van de longarts in te roepen. Dat model voldoet niet meer. Veel patiënten kunnen met hulp van de longarts door de huisarts opgevolgd worden. Door laagdrempelige consultaties, casuïstiekbesprekingen, zelfs door mee te denken over het protocol van de huisarts, kan de longarts betrokken worden bij de eerstelijns zorg. In onze regio hebben we met het oog op laagdrempelige, eenmalige consultaties in 2008 de zogenaamde ketenpoli ingericht. Daarvoor wordt gebruik gemaakt van de huisartsenpost die in ons ziekenhuis buiten kantooruren voor de SEH geschakeld is. Buiten kantooruren worden de ruimtes van de HAP niet benut, dus daar konden we met de ketenpoli terecht. Bovendien illustreert dat eens te meer dat de patiënt die daar gezien wordt alleen nog maar op de drempel van de tweede lijn is. Daar kunnen de longverpleegkundige en de longarts meekijken en meedenken in geval van twijfels aan de diagnose, bij uitblijven van het verwachte effect van behandeling en bij COPD-patiënten met matig complexe problematiek, onverwacht snelle achteruitgang van de longfunctie of de wens van de patiënt. Deze eenmalige consultatie bestaat uit een uitgebreid consult bij de longverpleegkundige en op indicatie uit een thoraxfoto, aanvullend longfunctieonderzoek (bodybox en/of diffusie) en een afrondend consult bij de longarts. Bovendien verzamelen we daar monsters van sputum en uitgeademde lucht om de rol van micro-organismen en de aard van het inflammatoire proces te kunnen bestuderen. Ook verzamelen we systematisch gegevens over de kwaliteit van leven van de patiënt en van het psychisch welbevinden. $\mathrm{Er}$ wordt gebruik gemaakt van een elektronisch patiëntendossier (MediX ${ }^{\circledR}$ ), dat voor alle zorgverleners beschikbaar is en waarin alle bevindingen van de consultatie worden opgetekend, inclusief het advies aan de huisarts. Het consult wordt niet in rekening gebracht bij de zorgverzekeraar maar bij de huisarts, die immers hoofdaannemer is. Vrijwel altijd blijft het 
bij een eenmalige consultatie en gaat de patiënt inclusief advies terug naar de huisarts en de praktijkondersteuner voor verdere begeleiding en behandeling.

We richten ons zeker in de tweede lijn bij de zorg voor patiënten met chronisch obstructieve longaandoeningen vanzelfsprekend vooral op patiënten met vergevorderde ziekte. Die komen immers naar het ziekenhuis voor behandeling. Die komen jammer genoeg rijkelijk laat. Een van de redenen daarvoor is dat verwijzing lange tijd de enige manier was om de expertise van de longarts bij de patiënt in te schakelen. Verwijzing is een zeer statische zorgmodaliteit. Lang niet alle verwijzingen zijn nuttig en patiënten die niet verwezen worden krijgen mogelijk niet of te laat wat ze nodig hebben. Het is niet zeker dat we ze in de tweede lijn eerder hadden kunnen helpen, maar tijdige diagnostiek en vroegtijdig ingrijpen en vooral voorkomen, zou waarschijnlijk veel meer gezondheidswinst opgeleverd hebben dan nu in de tweede lijn mogelijk is. Dat is een zorg die door veel longartsen wordt gedeeld, en aangezien ik over enkele weken het voorzitterschap van de Nederlandse Vereniging van Artsen voor Longziekten en Tuberculose op mij zal nemen word ik geacht aan het garanderen van de betrokkenheid van longartsen bij de zorg een bijdrage te leveren. Gelukkig zijn er op veel plaatsen in Nederland al initiatieven gestart om te verzekeren dat de expertise van de longarts bijtijds wordt ingeschakeld. Dat gebeurt op een aantal plaatsen in de vorm van astma/COPD diensten voor geprotocolleerde initiële diagnostiek of in de vorm van geprotocolleerde feedback op in de eerste lijn verrichte spirometrie. In de regio Heuvelland hebben we al jaren het model van de carrouse ${ }^{20}$. In dat model bezoeken specialisten van verschillende disciplines bij toerbeurt huisartspraktijken om daar samen patiënten te zien. Dat levert veel op. Je leert elkaar kennen en kijkt in elkaars keuken, je draagt kennis over en voorkomt zinloze verwijzingen en ik heb er jarenlang met veel plezier aan meegedaan.

Voor alle drie de genoemde modellen heeft in het land altijd veel belangstelling bestaan en er is over gerapporteerd, gepubliceerd en gepromoveerd.

We gaan nu starten met een tevredenheidonderzoek onder patiënten in het traject van de keten-DBC en naar een analyse van de allocatie van patiënten met obstructieve longaandoeningen. Bovendien gaan we aan de hand van een eerste in de praktijk bruikbare tool voor het objectiveren van de ziektelast en met de recentelijk overeengekomen conceptset van kwaliteitsindicatoren en een zorgvuldige opvolging van patiënten 
de effecten van het nu ingerichte zorgmodel trachten te bestuderen. Anders dan met vrijwel alle andere uitingen van marktwerking in de zorg zal de zorg met het nu ingerichte zorgmodel misschien niet duurder worden, maar nog steeds hebben we de verantwoordelijkheid om te laten zien dat de uitkomsten in termen van gezondheidswinst beter zijn.

\section{Cystic fibrosis}

Een belangrijk deel van mijn agenda als longarts is ingeruimd voor patiënten met de ziekte cystic fibrosis, ook wel taaislijmziekte genoemd. In zekere zin is dat ook een COLA maar dan wel een heel andere dan astma en COPD waarover ik eerder sprak. Cystic fibrosis, afgekort CF is een aangeboren, ernstige ziekte waaraan in Nederland ongeveer 1.300 patiënten lijden. Dat zijn dus heel andere getallen dan de honderdduizenden die lijden aan astma of COPD. CF-patiënten hebben abnormale concentraties van elektrolyten en secundair daaraan hoeveelheden watermoleculen in zweet en uitscheidingsproducten van verschillende klieren in het lichaam, wat vooral leidt tot ontstekingsverschijnselen in longen en luchtwegen en tot tekorten aan spijsverteringsenzymen in de tractus digestivus. We stellen de diagnose CF vaak al direct na de geboorte en dan begint er voor de patiënten en aanvankelijk natuurlijk voor de ouders een lange weg vol zorgen en vol zorg. Aanvankelijk betreft die zorg vooral optimale voeding en het zo goed mogelijk schoon en kiemvrij houden van de longen. Al snel komen daar geneesmiddelen bij die patiënten in steeds toenemende aantallen levenslang zullen moeten blijven gebruiken. Enkele van die geneesmiddelen zijn speciaal ontwikkeld voor CF. Veel bij CF ingezette middelen zijn evenwel niet speciaal bedoeld voor CF en vaak ook niet eens bij CF getest. Toch worden ze veel voorgeschreven in de veronderstelling dat ze ook bij CF helpen, een aanname waarvoor nog veel doelmatigheidsonderzoek noodzakelijk is dat er waarschijnlijk nooit zal komen.

Net als bij de andere COLA komen daar voor CF-patiënten nog bij de leefstijladviezen niet roken, zoveel mogelijk bewegen en zorgen voor een goede voedingstoestand die ook van toepassing zijn voor patiënten met andere chronische aandoeningen.

Door dit alles is de levensverwachting van CF-patiënten de afgelopen decennia spectaculair verbeterd. Onderstaande afbeelding komt uit een Engelse publicatie uit 2007 en betreft gegevens verzameld tot en met $2004^{21}$. De tweede afbeelding laat zien dat ook de levensverwachting van patiënten met vergevorderde longschade ten gevolge van CF de afgelopen decennia verder is verbeterd ${ }^{22}$. 


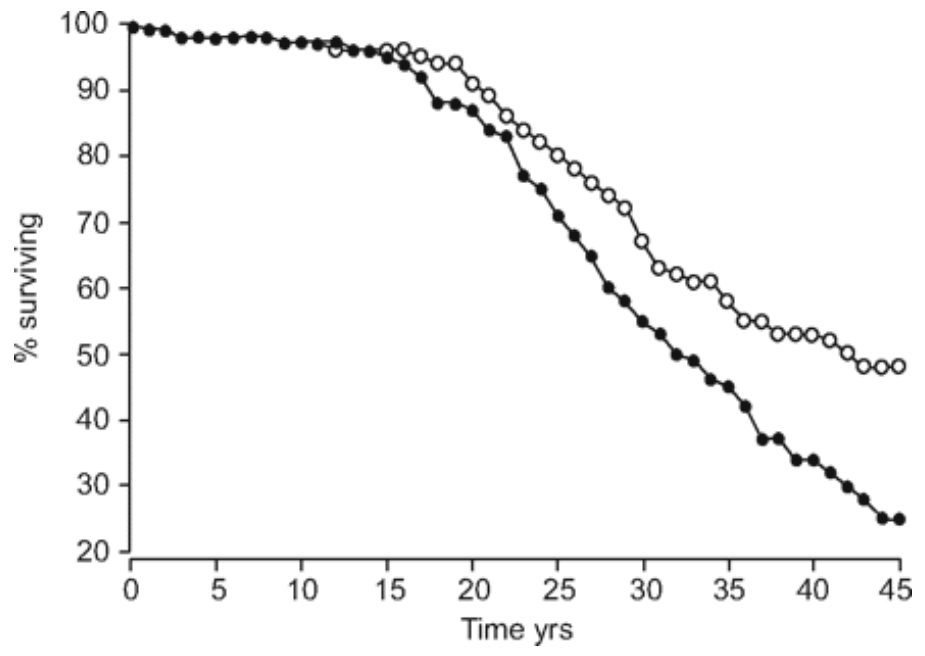

Levensverwachting van patiënten met CF in het Verenigd Koninkrijk (uit referentie 21).

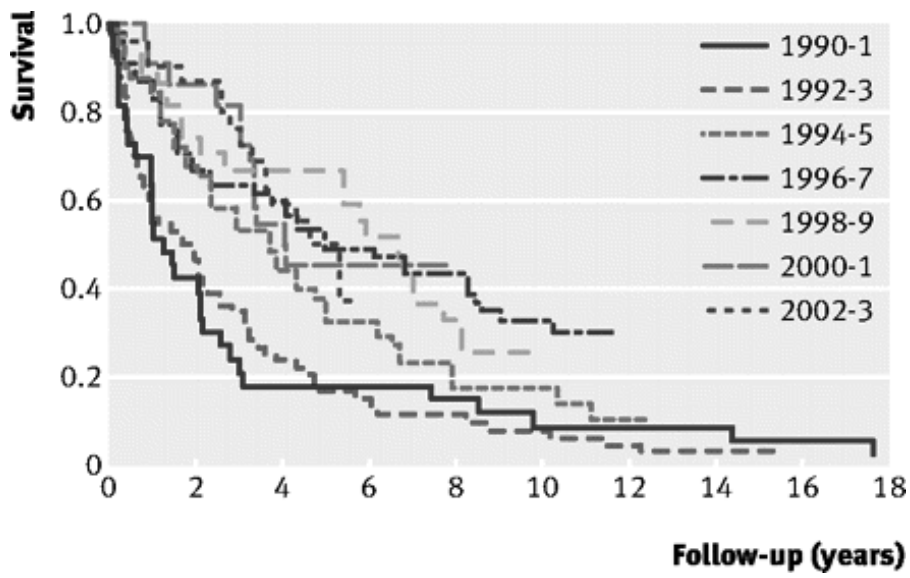

Overleving van CF patiënten met zeer ernstige luchtwegvernauwing (FEV1 $<30 \%$ van voorspeld) (uit referentie 22).

Anno 2011 bereiken de meeste CF-patiënten de volwassen leeftijd en is CF niet langer een kinderziekte maar ook een ziekte waar een aantal van mijn soort longartsen in toenemende mate mee te maken krijgen en zich voor inzetten. 
Ondanks alle inspanningen van patiënten, ouders en behandelaars moeten CF-patiënten leven met de wetenschap van een verminderde levensverwachting en de dreiging van en later ook dagelijkse confrontatie met toenemende klachten en beperkingen die een normaal leven als volwassene bijna altijd onmogelijk maken. Bovendien valt het niet mee om de vele geneesmiddelen en leefstijladviezen nauwgezet te blijven opvolgen, al was het al vanwege de tijd die er dagelijks mee gemoeid is. De multidisciplinaire en complexe zorg voor CF-patiënten wordt in een beperkt aantal centra in Nederland geboden en het Maastricht UMC+ is zo'n centrum. De grootste uitdaging bij het inrichten en aanbieden van die zorg is de balans te vinden tussen wat er volgens ons als behandelaars allemaal moet gebeuren en wat de patiënt kan en wil opbrengen in het streven een zo normaal mogelijk leven te leiden.

\section{Dossiervorming}

In het structuurrapport bij deze leerstoel is ook een passage gewijd aan de ontwikkeling en implementatie van het nieuwe ziekenhuisinformatiesysteem en het elektronisch patiëntendossier. "Kosten EPD ruim 300 miljoen euro" kopte de NRC enkele weken geleden op de voorpagina. Nu gaan er al langere tijd geruchten over de hoge kosten van de introductie van het SAP in ons ziekenhuis maar het bedrag van 300 miljoen euro had ik in die context nog niet gehoord. Het bleek gelukkig te gaan om het landelijk EPD waarover al jaren veel te doen is. Gevreesd wordt dat een groot deel van dat geld weggegooid zal blijken te zijn, zeker nu de eerste kamer daarover negatief besloot. Daarmee lijkt het moment dat iedere zorgverlener op het moment dat dat nodig is beschikt over actuele medicatiegegevens en relevante diagnoses verder weg dan ooit.

Zo moeilijk zou dat toch niet moeten zijn, zou je denken. Alleen al op iedere noodzakelijke plaats beschikken over informatie over welke medicamenten een patiënt precies gebruikt, geobjectiveerde allergieën en risicofactoren, eerder gestelde diagnoses en belangrijke operaties zou de veiligheid van patiënten die elders behandeling zoeken zeer ten goede komen. Het lijkt erop dat het probleem van de bescherming van de privacy van patiënten in de discussie het zwaarst weegt. Daar moet een mouw aan te passen zijn want dat bezwaar geldt niet alleen een eventueel in te voeren landelijk EPD maar ook het EPD dat in ziekenhuizen zoals het azM of regionaal ontwikkeld wordt. De investeringen die het azM zich getroost om een nieuw ziekenhuisinformatiesysteem te ontwikkelen en te implementeren, inclusief het eraan gekoppelde EPD zullen zeker geen weggegooid geld zijn. Vooral niet als dat er uiteindelijk toe leidt dat alle 
relevante en actuele gegevens direct bij de patiënt te raadplegen zijn, dat nieuwe informatie op eenvoudige en eenduidige wijze aan het dossier kan worden toegevoegd, dat verschillende bij één patiënt betrokken behandelaars tijdig geïnformeerd zijn en elkaar kunnen informeren, dat de naleving van protocollen en richtlijnen door het systeem wordt bevorderd, bij voorkeur door elementen van decision support. Daarmee kunnen behandelaars geholpen worden bij het naleven van richtlijnen kunnen opdrachten voor diagnostiek en behandeling en recepten foutloos en papierloos worden verwerkt. Zover zijn we nog lang niet. Vooralsnog zijn alle handelingen die verbonden zijn aan het werken met het EPD zoals we dat nu kennen geweldig tijdrovend en hebben velen van ons nog niet het idee dat het systeem hen ondersteunt in de dagelijkse zorg. Het tegenovergestelde lijkt eerder het geval, ook al omdat de administratieve overhead alleen maar lijkt toe te nemen. Denk maar eens aan het correct registreren van DBC's, het invoeren van orders, het genereren van ontslagbrieven en andere correspondentie en het maken van medicatieopdrachten. Wat vroeger met pen en papier secondenwerk was is voor mijn soort mensen inmiddels een tijdrovende bezigheid. De generatie na mij zal meer vertrouwd zijn met het werken met de computer maar af en toe lijkt de opleiding tot medisch specialist eerder op een cursus computervaardigheden dan op de opleiding zoals ik die uit mijn tijd nog ken.

Bovendien zijn op dit moment op de verpleegafdelingen patiëntgegevens niet direct aan het bed te raadplegen of aan te vullen. Natuurlijk lopen we over 10 jaar met tablet-pc's visite of is bij ieder bed een monitor beschikbaar waarmee dat mogelijk is. Voorlopig is er evenwel eerder sprake van visite zitten dan van visite lopen en wordt tijdens de visite meer tijd besteed voor de desktop computer dan aan het bed. Dat heeft voor mijn gevoel ook consequenties voor opleidingen tot medisch specialist, één van de kerntaken van een ziekenhuis als het onze. Ook bij dat opleiden dient de patiënt centraal te staan en visite lopen met de supervisor of opleider samen met een verpleegkundige die de patiënt kent en coassistenten en semiartsen die aan het bed uitgenodigd en uitgedaagd worden om mee te denken en mee te doen is daarvan een cruciaal onderdeel. 


\section{Onderwijs}

Was het maar zo makkelijk, de titel van mijn oratie is zeker ook van toepassing op het onderwijs aan de faculteit geneeskunde, of FHML, zoals die sinds enkele jaren heet. Het idee achter probleemgestuurd onderwijs is heel eenvoudig. Je legt de ambitieuze en nieuwsgierige jongelui, die geneeskundestudenten natuurlijk zijn, een interessant probleem voor en met elkaar lossen ze dat probleem op. Op die manier doen ze in 6 jaar de kennis en de vaardigheden met een moderner woord competenties op die ze nodig hebben om een goeie dokter te worden. Dat klinkt eenvoudig, maar als je ziet wat daar allemaal bij komt kijken, dan realiseer je je dat het zo eenvoudig niet is. Er gaan geweldig veel uren zitten in het maken van het lesmateriaal of curriculum, het aanleren van technische en communicatieve vaardigheden, bijvoorbeeld in het skillslab, het organiseren van patiëntencontacten tijdens de coschappen en vooral ook het ontwikkelen en implementeren van een stelsel van toetsen, beoordelingen en examens waarmee je de voortgang van de student bewaakt, en garandeert dat de eindtermen van de studie door zoveel mogelijk studenten in de daarvoor afgesproken 6 jaar worden bereikt.

Ik ben de afgelopen jaren veel te gast geweest bij geneeskundefaculteiten in verschillende buitenlanden om mee te helpen daar een zo goed mogelijk curriculum voor de studie geneeskunde te ontwikkelen en te implementeren. Met name betreft het daarbij het optimaal benutten van patiëntencontacten als leermiddel voor geneeskundestudenten. Vaak met veel minder middelen, altijd met veel minder mensen en nogal eens met studenten die bij de aanvang van hun studie niet de bagage meebrengen die onze eerstejaars studenten van de middelbare school meekrijgen. Onze studenten gaan tijdens hun zesjarige studie door honderden handen en al die handen dragen in meer of mindere mate bij aan het eindproduct basisarts. Dat is geweldig kostbaar, zeker als het gaat om contacten en leermomenten met echte patiënten in de werkelijkheid van de zorg en de vraag is of onze faculteit daarvoor de middelen blijft houden. Ik heb begrepen dat er ook daar bezuinigd moet worden, terwijl iedereen ernaar blijft streven om de kwaliteit van het onderwijs te blijven verbeteren. Meer met minder dus en ik hoop de ervaring van mijn buitenlandse inspanningen te kunnen inzetten in het streven om met de beschikbare middelen een zo optimaal mogelijk curriculum te blijven garanderen. 


\section{Dames en heren,}

De titel van mijn oratie klinkt misschien als een verzuchting. Ik zie het hiervoor geschetste evenwel vooral als een uitdaging.

Het is een uitdaging om obstructieve longaandoeningen tijdig en adequaat te diagnosticeren en daarbij te garanderen dat de expertise van alle bij de zorg betrokken zorgverleners op een laagdrempelige, transparante en doelmatige wijze zo dicht mogelijk bij de patiënt kan worden aangeboden. Het is een uitdaging om rokers met roken te laten stoppen, patiënten in beweging te krijgen en overgewichtenondervoeding tegen te gaan. Het is een uitdaging om interventies en behandelingen en combinaties daarvan te ontwikkelen en te implementeren die voor de patiënt het verschil maken en die ook op de lange termijn betaalbaar blijven. Het is een uitdaging om een gebruikersvriendelijk en veilig geïntegreerd, transmuraal elektronisch patiëntendossier te ontwikkelen en te implementeren. En het is een uitdaging om met een krimpende staf en een almaar groeiende patiëntenzorgbelasting de beste faculteit geneeskunde van Nederland te blijven.

Dat allemaal zijn uitdagingen voor onderzoekers en voor zorgverleners. Ik ben zeker niet de jongste die hier ooit in deze hoedanigheid heeft gestaan maar het besluit van het vorige kabinet om de AOW-gerechtigde leeftijd langzaam te verhogen stelt mij ten minste 1 jaar langer in de gelegenheid om deze uitdaging aan te gaan.

Rest mij enkele woorden van dank. Ik ben dit jaar 25 jaar in Maastricht en heb van heel veel mensen, te veel om op te noemen, veel geleerd, als arts-assistent, als staflid, als lid van het stafconventsbestuur, als lid van het faculteitsbestuur en van de betrokkenheid bij onderwijs, onderzoek en patiëntenzorg in deze instelling. Ik ben allen die het betreft daar dankbaar voor. Speciaal dank ik Miel Wouters, één van mijn opleiders, mijn promotor in 1993 en het hoofd van onze afdeling voor alle steun en het in mij gestelde vertrouwen. Ik dank ook Onno van Schayck, directeur van CAPHRI voor de steun en de plezierige samenwerking. Ik dank mijn collega-longartsen, van wie ik hier met name graag Guul ten Velde noem, voor steun en voor de ruimte die ze me gaven om mijn ding te doen.

Zonder mijn ouders, hun steun en hun vertrouwen was ik wie ik ben niet geworden. Lieve pa en ma, geweldig dat jullie hier vandaag getuige van mogen zijn, en dat geldt ook voor mijn schoonmoeder.

Het grapje over het snijden van het vlees op zondag zal ik vandaag niet maken maar onze 2 jongens Pieter Maarten en Frederik hebben het vaak zonder mij moeten doen. Het is gelukkig goed gekomen. 
De meeste dank ben ik verschuldigd aan mijn vrouw Jetske. Ik zal niet uitweiden over wat ze met me te stellen heeft gehad maar zonder haar geduld, vertrouwen en liefde had ik hier vandaag niet gestaan. Ik heb gezegd. 


\section{Referenties}

1 Hutchinson J. On the capacity of the lungs, and on the respiratory functions, with a view of establishing a precise and easy method of detecting disease by the spirometer. Med Chir Trans 1846; 29:137-252

2 Petty TL. John Hutchinson's mysterious machine revisited. Chest 2002; 121:219S-223S

3 Postma DS, Boezen HM. Rationale for the Dutch hypothesis. Allergy and airway hyperresponsiveness as genetic factors and their interaction with environment in the development of asthma and COPD. Chest 2004; 126:96S-104S; discussion 159S-161S

$4 \mathrm{NHLBI/WHO}$. Global Initiative for Chronic Obstructive Lung Disease, Global strategy for the diagnosis, management and prevention of chronic obstructive pulmonary disease. In: 2003 NWWRu, ed: Available from: URL: http://www.goldcopd.com, 2003

5 Kerngetallen SSF. Zorgondersteuning bij astma/COPD verbeterd. Pharmaceutisch weekblad 2011; Jaargang 146: http://www.sfk.nl/publicaties/farmacie_in_ijfers/2011/2011-2009.html

6 Gommer A, Poos M. Cijfers Astma. Prevalentie, incidentie en sterfte. Volksgezondheid Toekomst Verkenning, Nationaal Kompas Volksgezondheid. 2010; Nationaal Kompas Volksgezondheid। Gezondheiden ziekte\Ziekten en aandoeningen\Ademhalingswegen\ Astma

7 Maas T, Kaper J, Sheikh A, et al. Mono and multifaceted inhalant and/ or food allergen reduction interventions for preventing asthma in children at high risk of developing asthma. Cochrane Database Syst Rev 2009:CDoo6480

8 Rabe KF, Vermeire PA, Soriano JB, et al. Clinical management of asthma in 1999: the Asthma Insights and Reality in Europe (AIRE) study. Eur Respir J 2000; 16:802-807

9 Gommer A, Poos M. Cijfers COPD. Prevalentie, incidentie en sterfte. Volksgezondheid Toekomst Verkenning, Nationaal Kompas Volksgezondheid. 2010; Nationaal Kompas Volksgezondheid Gezondheiden ziekte\Ziekten en aandoeningen\Ademhalingswegen\ COPD

10 Boushey H, Enright P, Samet J. Spirometry for chronic obstructive pulmonary disease case finding in primary care? Am J Respir Crit Care Med 2005; 172:1481-1482

11 Prevention EENfsaT. News Release: Healthcare professionals urge better education for doctors to help smokers quit.

http://www.ensp.org/node/604 2011 
12 Stivoro. Kerncijfers roken in Nederland.: http://www.stivoro.nl/ upload/Kerncijfers\%2oroken\%20in\%20Nederland\%202010.pdf, 2010

13 Kotz D, van Litsenburg W, van Duurling R, et al. Smoking cessation treatment by Dutch respiratory nurses: reported practice, attitudes and perceived effectiveness. Patient Educ Couns 2008; 70:40-49

14 Parkes $G$, Greenhalgh T, Griffin $M$, et al. Effect on smoking quit rate of telling patients their lung age: the Stepzquit randomised controlled trial. BMJ 2008; 336:598-600

15 Kotz D, Wesseling G, Huibers MJ, et al. Efficacy of confronting smokers with airflow limitation for smoking cessation. Eur Respir J 2009; 33:754-762

16 DIEP. Diabetes Interactief Educatie Programma:

http://www.diep.info/index.php

17 Halpin DM. Lessons from the major studies in COPD: problems and pitfalls in translating research evidence into practice. Prim Care Respir J 2010; 19:170-179

18 Vrijhoef HJ, Van Den Bergh JH, Diederiks JP, et al. Transfer of care for outpatients with stable chronic obstructive pulmonary disease from respiratory care physician to respiratory nurse--a randomized controlled study. Chronic Illn 2007; 3:130-144

19 Steuten L, Vrijhoef B, Van Merode F, et al. Evaluation of a regional disease management programme for patients with asthma or chronic obstructive pulmonary disease. Int J Qual Health Care 2006; 18:429-436

20 azM. Gezamenlijk consult (carrousel). Maastricht: http://www.azm.nl/info/azMorganisatie/57314/57316/57350

21 Dodge JA, Lewis PA, Stanton M, et al. Cystic fibrosis mortality and survival in the UK: 1947-2003. Eur Respir J 2007; 29:522-526

22 George PM, Banya W, Pareek N, et al. Improved survival at low lung function in cystic fibrosis: cohort study from 1990 to 2007. BMJ 2011; 342:d1008 
